\title{
Dietary determinants of vitamin $D$ intake in Irish pre-school children aged 1-4 years
}

\author{
L. Kehoe ${ }^{1}$, J. Walton ${ }^{1}$, B. McNulty ${ }^{2}$, A. Nugent ${ }^{2}$ and A. Flynn ${ }^{1}$ \\ ${ }^{1}$ School of Food and Nutritional Sciences, University College Cork, Republic of Ireland and ${ }^{2}$ UCD Institute of Food \\ and Health, University College Dublin, Belfield, Dublin 4, Republic of Ireland
}

The early years of life are a critical period in the life cycle and adequate intakes of nutrients are essential for healthy growth and development. It has previously been reported that intakes of vitamin D are generally low in Irish children with $70-84 \%$ of $1-4$ year olds having intakes less than $5 \mu \mathrm{g} / \mathrm{d}^{(1)}$ The objective of this analysis was to identify the dietary determinants of vitamin D intakes in $1-4$ year old Irish children based on data from the National Pre-School Nutrition Survey (2010-2011) (www.iuna.net). A 4-day weighed food record was used to collect food intake data of 500 pre-school children. Analysis of dietary intake data was carried out using WISP $^{\odot}$ based on McCance and Widdowson's The Composition of Foods ${ }^{(2)}$ and the Irish Foods Composition Database. ${ }^{(3)}$ The $^{\circ}$ mean daily intake of vitamin D was $4 \cdot 5,3 \cdot 7,3 \cdot 4$ and $3 \cdot 2 \mu \mathrm{g} / \mathrm{d}$ for $1,2,3$ and 4 year olds, respectively. On the basis of mean daily vitamin D intake, children were divided into three intake groups: low medium or high consumers, stratified by age. The food groups which accounted for the greatest proportion of the difference in intakes between the high (top third) and low (bottom third) consumers of vitamin $\mathrm{D}$ by age were identified.

\begin{tabular}{|c|c|c|c|c|}
\hline \multirow[b]{2}{*}{ Age } & \multicolumn{3}{|c|}{$\begin{array}{l}\text { Mean daily Vitamin D } \\
\text { intake }(\mu \mathrm{g} / \mathrm{d})\end{array}$} & \multirow[b]{2}{*}{$\%$ Contribution of food groups to the difference between high and low consumers } \\
\hline & Low & High & Difference & \\
\hline $\begin{array}{l}1 \text { year olds }(12-23 \\
\text { months) }\end{array}$ & $1 \cdot 16$ & 9.82 & 8.66 & $\begin{array}{l}\text { GUM/IMF (59), Nutritional supplements (24), Fortified milks (8), Breakfast cereals (5), Yoghurt \& Fromage } \\
\text { frais (2) }\end{array}$ \\
\hline $\begin{array}{l}2 \text { year olds }(24-35 \\
\text { months) }\end{array}$ & $1 \cdot 23$ & $7 \cdot 49$ & $6 \cdot 26$ & $\begin{array}{l}\text { GUM/IMF (41), Nutritional supplements (33), Fortified milks (14), Yoghurt \& Fromage frais (3), Breakfast } \\
\text { cereals (5) }\end{array}$ \\
\hline $\begin{array}{l}3 \text { year olds }(36-47 \\
\text { months) }\end{array}$ & $1 \cdot 18$ & $6 \cdot 68$ & $5 \cdot 51$ & $\begin{array}{l}\text { Nutritional supplements (56), Fortified milks (18), GUM/IMF (11), Yoghurt \& Fromage frais (4), Breakfast } \\
\text { cereals (2) }\end{array}$ \\
\hline $\begin{array}{l}4 \text { year olds }(48-59 \\
\text { months) }\end{array}$ & $1 \cdot 21$ & $6 \cdot 03$ & $4 \cdot 81$ & $\begin{array}{l}\text { Nutritional supplements (44), Fortified milks (26), Yoghurt \& Fromage frais (5), Fish \& fish dishes (5), Breakfast } \\
\text { cereals (4) }\end{array}$ \\
\hline
\end{tabular}

GUM = Growing-up milks, IMF = Infant milk formula

The greatest difference in vitamin D intake between high and low consumers was observed for one year olds ( $8.7 \mu \mathrm{g} / \mathrm{d})$. For 1 and 2 year olds, GUM/IMF accounted for the greatest difference in vitamin D intakes between high and low consumers (59\% and $41 \%$ respectively). Nutritional supplements made an important contribution to the difference in vitamin $\mathrm{D}$ intakes between high and low consumers at all ages but particularly for 3 and 4 year olds (56\% and $44 \%$ respectively). The contribution to the difference in vitamin D intakes between consumer groups from fortified milks (other than GUM/IMF) increased from 1 to 4 years $(8 \%$ for 1 year olds vs. $18 \%$ for 3 year olds and $26 \%$ for 4 year olds). This is attributable to an increase in fortified milk consumers from age 1 to 4 years in line with a decrease in consumption of GUM/IMF. These findings demonstrate the importance of developing agespecific dietary guidelines to improve vitamin $\mathrm{D}$ intakes in pre-school children.

The project was funded by the Irish Department of Agriculture, Food and the Marine under the Nutridata Project 13 F 542; $2014-2016$.

1. Hennessy Á, Walton J, McNulty B et al. (2012) Proc Nutr Soc. 71(OCE2): E37.

2. Food Standards Agency (2002) McCance \& Widdowson's The Composition of Foods Fifth \& Sixth Editions including supplemental volumes. Cambridge: Royal Society of Chemistry.

3. Black LJ, Ireland J, Møller A et al. (2011) J Food Compost Anal. 24(7), 1017-1023. 